\title{
ON LANDSCAPES, MAPS AND UPPER PALEOLITHIC LIFESTYLES IN THE CENTRAL EUROPEAN CORRIDOR: THE IMAGES OF PAVLOV AND PŘEDMOSTÍ
}

\author{
SOBRE PAISAJES, MAPAS Y SISTEMAS DE VIDA \\ DEL PALEOLÍTICO SUPERIOR EN EL CORREDOR CENTROEUROPEO: \\ LAS IMÁGENES DE PAVLOV Y PŘEDMOSTÍ
}

\author{
Jiri SVOBODA \\ jsvoboda@sci.muni.cz
}

DOI: $10.1387 /$ veleia.18074

\begin{abstract}
In the context of recent discussions on early modern human capacities of timeawareness, space-awareness, planning and organized hunting, this paper presents three complex Gravettian engravings on mammoth tusks or ivory plaques from the sites of Pavlov and Předmostí in central Europe and suggests their possible interpretations as «maps» and/or «hunting plans».

Keywords: Central Europe, knowledge of the landscape, planning, Gravettian.

Resumen: En el contexto de los debates recientes sobre las capacidades humanas modernas relativos a la conciencia del tiempo y del espacio, la planificación y la caza organizada, este artículo presenta tres grabados gravetienses sobre colmillos de mamut y placas de marfil de los yacimientos de Pavlov y Předmostí en Europa central, sugiriendo sus posibles interpretaciones como «mapas» y/o "planes de caza».

Palabras clave: Europa central, conocimiento del paisaje, planificación, Gravetiense.
\end{abstract}

Recibido: 23-02-2017

Informado: 20-03-2017

Definitivo: 17-04-2017

\section{Hunters' approach to SPACE}

Human evolution is understood as a fundamental cognitive advance, related to possible reorganization of the brain, origins of speech, planning, symbolic behavior, and creating symbolic representations - so-called art. A discussion still continues on whether the appearance of this complex human behavior was a sudden effect related to the Upper Paleolithic in Eurasia, or if its individual components may be traced back to the Middle Stone Age record in Africa. Certainly, defining time and space creates the dimensions in which the formation and development of any 
symbolic meaning may take place. Therefore, time-awareness and space-awareness range among the important components of the Upper Paleolithic adaptation system.

We generally assume that the attitude of hunters to space is more or less patterned (Klíma 1988; Svoboda 2007; Utrilla et al. 2009; García-Diez, Vaquero 2015). On the "mammoth steppes" in North Eurasia, patterns of spatial relationships during the Upper Paleolithic are clearly reflected by archaeological mapping of sites. Specifically, the Gravettian sites follow large rivers and concentrate at narrow passages or bottlenecks ("gates"), and other places of strategic significance. This strategy, and awareness of such a strategy, is especially well documented at the Gravettian sites in the Lower Austrian-Moravian geographic corridor, such as Willendorf, Krems, Dolní Věstonice-Pavlov, Předmostí and Petřkovice (Otte 1981, 1992; Hahn 1987; Absolon, Klíma 1977; Klíma 1955, 1963, 1995; Svoboda 1984, 1994, 1997).

Ethnology provides us with rich evidence of how recent hunters-gatherers produce simple but practical "maps" and give names to geographic features in the landscape (Figure 1). During this process, recent populations focus rather on practical features of the landscape that are directly related to resources and to modes of their exploitation - hunting, gathering or fishing - and neglect other visible landmarks that are unimportant for practical tasks. Among many examples, we can cite Mallery's (1886) documentation of a story transmitted in a two-dimensional representation: Lean-Wolf, a Hidatsa Indian, walked from his home village along the Missouri to a Dakota village to steal horses, and returned successfully riding a stolen horse. Besides the narrative aspect of the story, the picture provides information about the two villages, their internal structure and the river network between them (Figure 2).

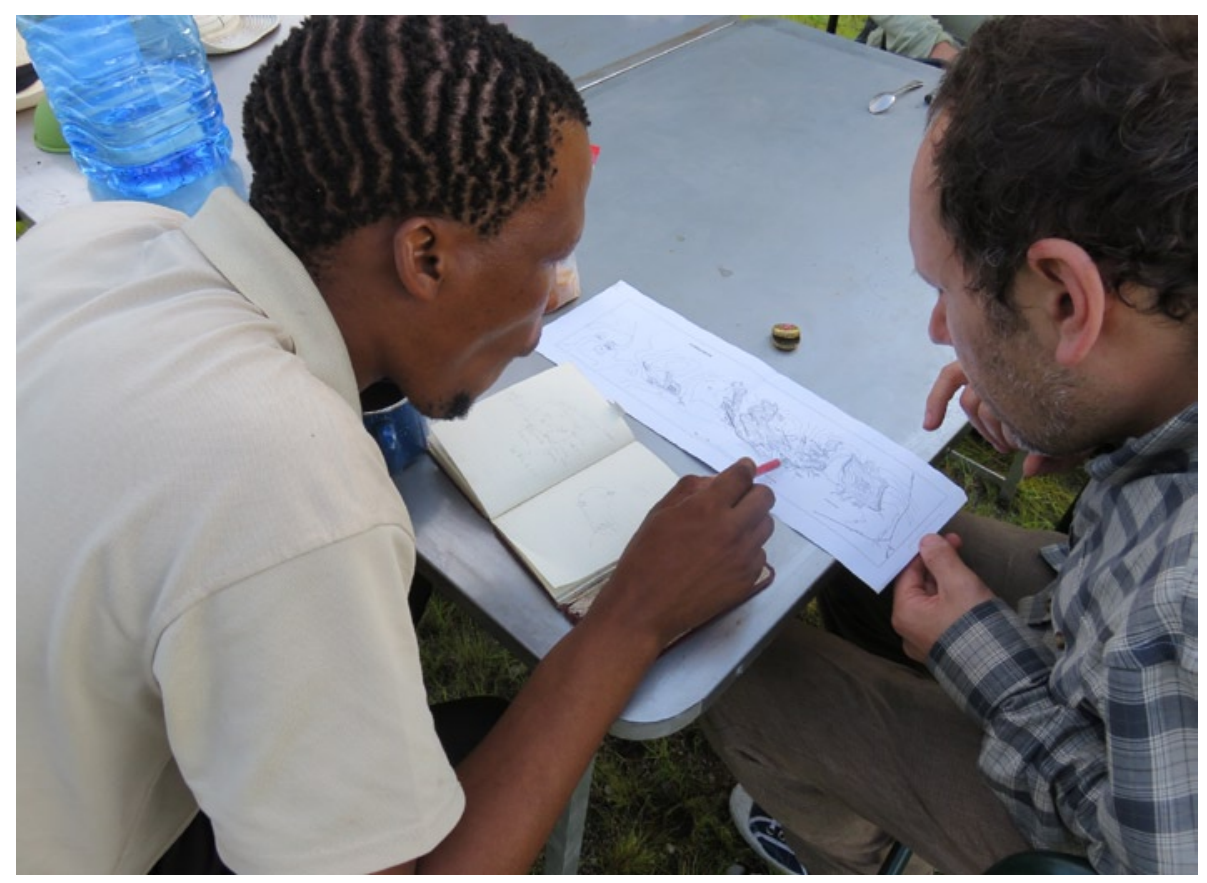

Figure I. Reading and drawing maps together with a local San guide, Botswana 2017 (photo J. Svoboda) 


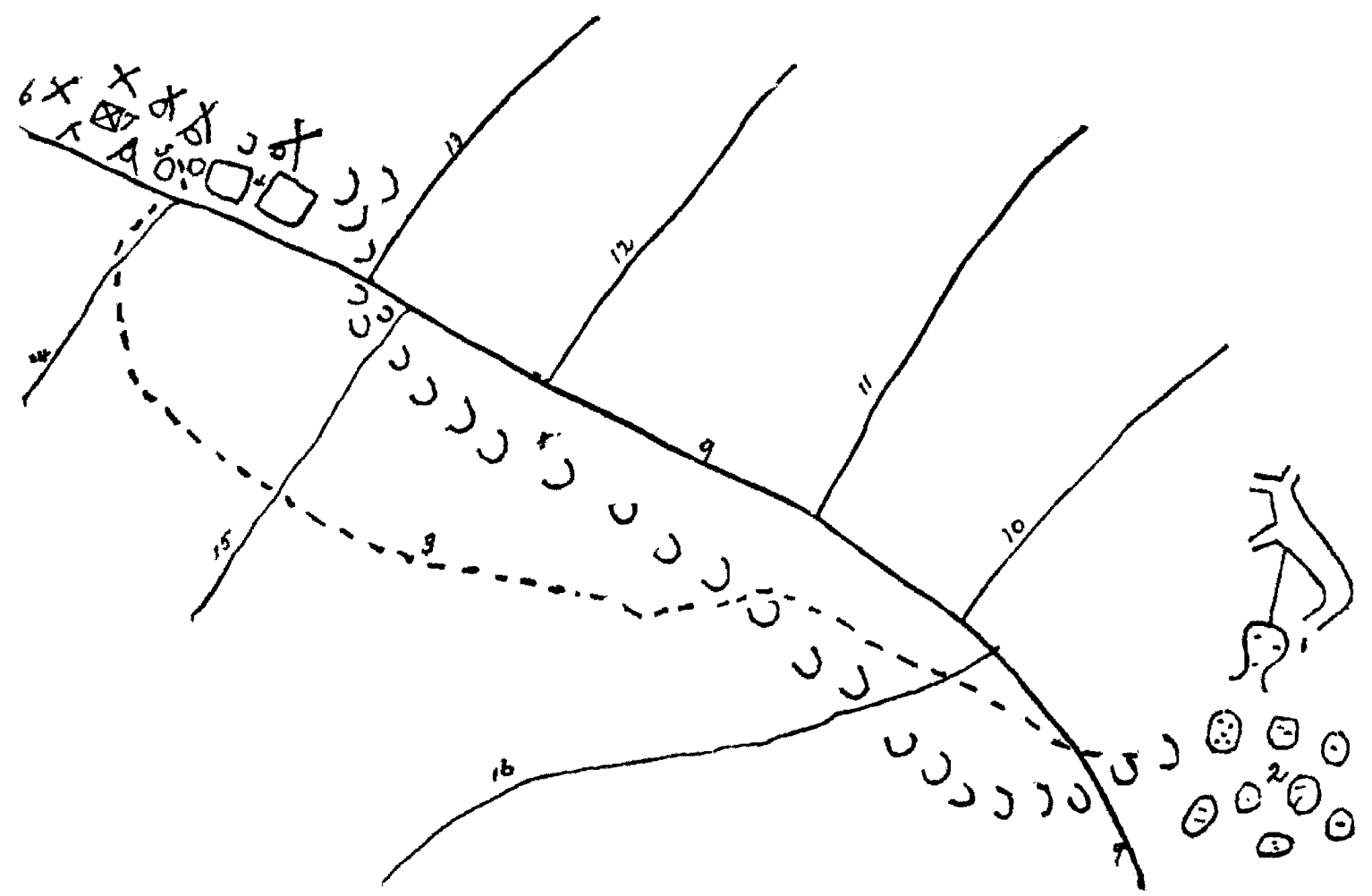

FIGURE 2. A Hidatsa Indian story transmitted in a two-dimensional representation (after Mallery 1886)

In this context, several Gravettian engravings from Moravia, Ukraine and Russia, all on mammoth tusks or ivory plaques, may be interpreted as two-dimensional representations of landscape and of hunters' activities within this landscape. Two Moravian cases, Pavlov and Předmostí, are discussed in more detail.

\section{Discussion: the evidence from Pavlov and Předmostí}

At the site of Pavlov in South Moravia, Bohuslav Klíma (1988) discovered a highly complex geometric pattern engraved on a mammoth tusk, and interpreted it as a sort of "map". In his view, the pattern shows the meandering river (center-left), the mountain behind (center-right) and the living site represented by a small double circle in the center of this landscape. At first sight, this idea seems difficult either to defend or to oppose, but it becomes more meaningful in the context of analogies from the Eurasian steppes. These were provided by similar complex patterns from Kiev-Kirillevskaia Street (Ukraine), Eliseevichi and Mezhirich (Ukraine), Trou Magritte (Belgium) and possibly by other cases (see Kozlowski 1992 fig. 94 and Marshack 1979, figs. 29 and 42). At Kirillevskaia, the analogy is underpinned by the use of a mammoth tusk as the surface (the second case is a reindeer antler), by the complexity of the pattern and by a similar sign possibly pointing to the living site (Figures 3-4). 


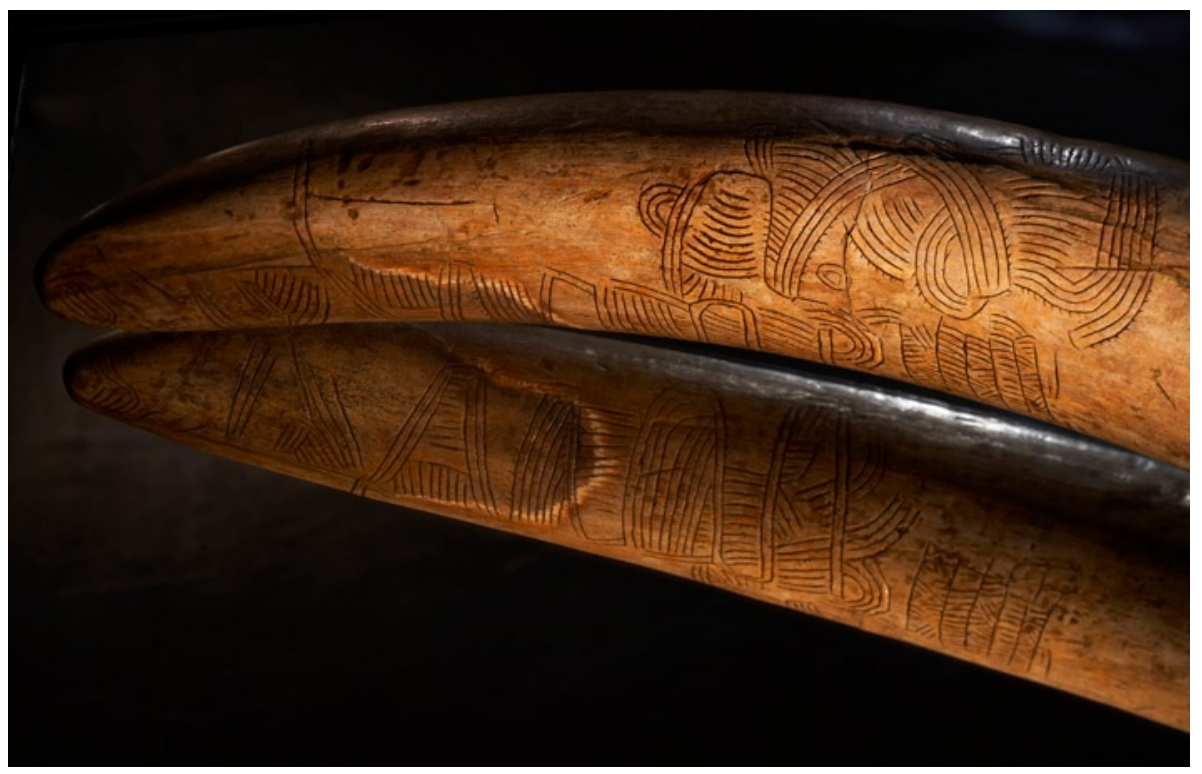

Figure 3. Pavlov $I$, a complex geometric engraving. Mammoth tusk, total length: $36.5 \mathrm{~cm}$ (photo by M. Frouz)

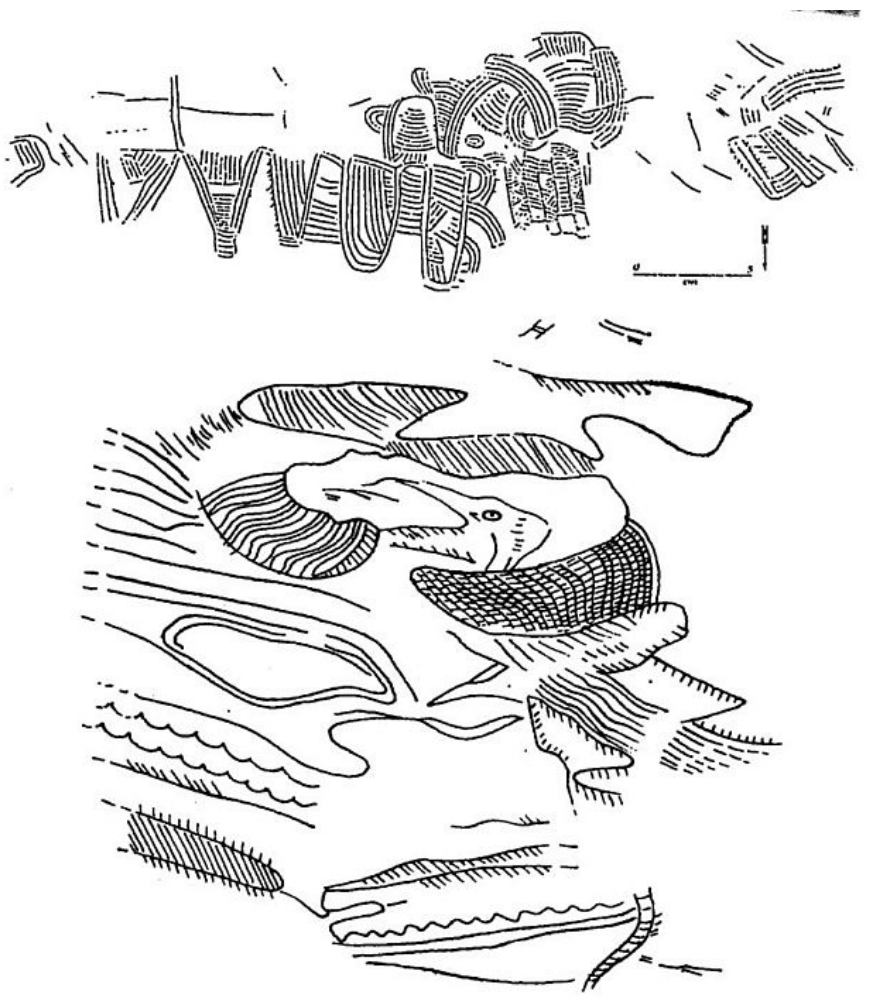

Figure 4. Pavlov I and Kirillevskaya, comparison of two geometric drawings 
In all three cases, a variety of linear symbols were used and combined, and these were usually considered simply as decorative patterns "to fill the space". Given the analogies with recent hunter-gatherers, however, it is possible that the linear symbols, with their curvature and hatching, represent landforms and their qualities, such as rivers, slopes, accessibility to animals and humans, or natural barriers. In light of this, the Pavlov tusk probably does not intend to display the Pavlov Hill skyline and the river, but, rather, provides utilitarian information about how the river valley and the slopes above may be used for driving animal herds and creating the optimal hunting strategy.

Two mammoth tusks showing complex geometric engravings from the site of Předmostí, about $80 \mathrm{~km} \mathrm{NE}$ of Pavlov, may be added to complete the picture. The first one was found in the 19th century excavations at Předmostí: it was later cleaned of its calcareous crust by Bohuslav Klíma in 1990 and interpreted as a simple female figure, possibly a preparatory sketch for the second, more complex, female engraving (Figures 5-6). The second piece was discovered by Martin Kříž in 1895 and interpreted by him as a geometric engraving, to be recognized later as a stylized female representation by Karel J. Maška; today, it is one of the best-known artifacts in Moravian Gravettian art.

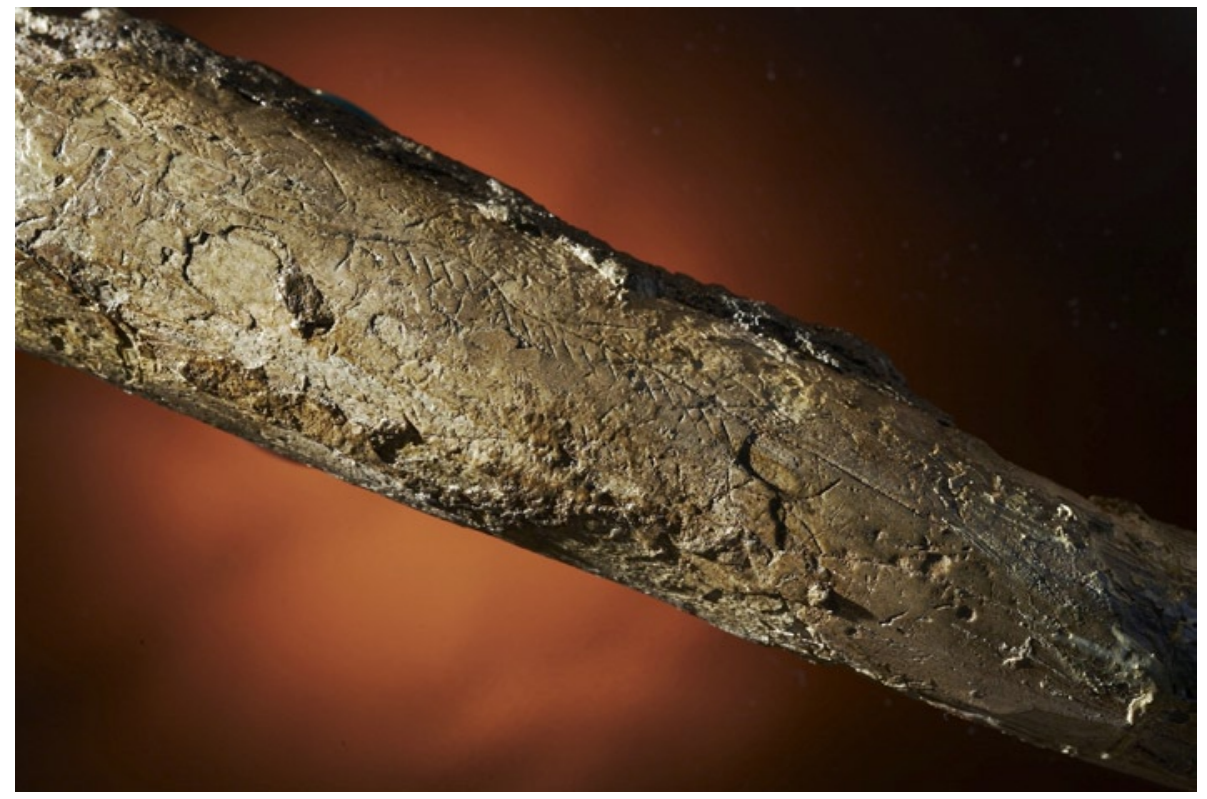

FIgURe 5. Predmosti $I$, a simple linear engraving, interpreted alternatively as a female or a map of the valley. Mammoth tusk (photo by M. Frouz)

Předmostí is a typical mammoth-hunting site controlling the southern exit of the Moravian Gate, which was the most important passage for large animal herds and hunters within the whole system of Lower Austrian-Moravian natural corridors. Comparing the first simple drawing with the actual landscape, the two lines that Klíma interpreted as outlines of a female body may correspond to the valley slopes and the short diagonal lines may provide additional information about their quality or accessibility. The two arches recalling female breasts refer to the bottleneck of the 

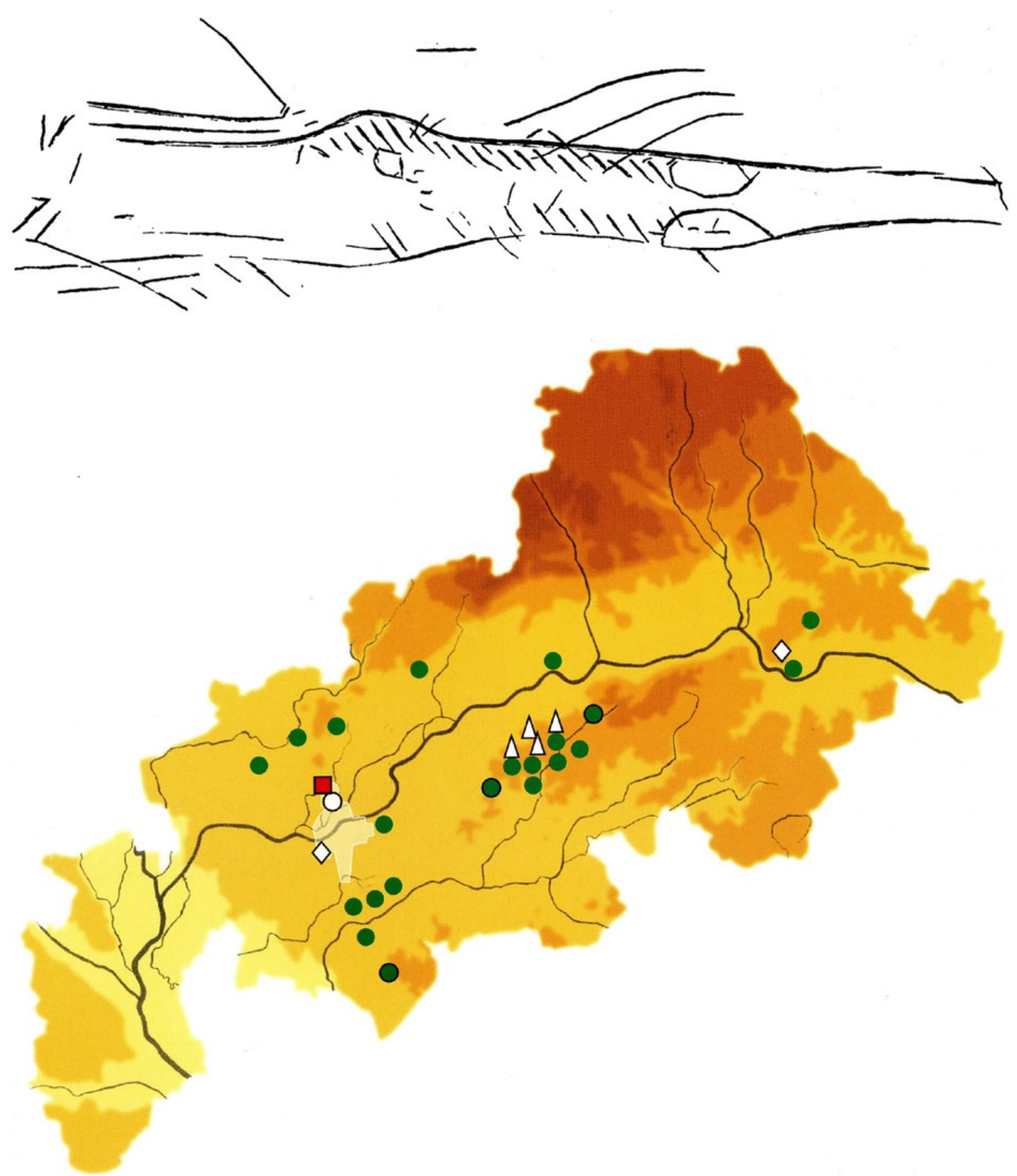

Figure 6. Predmosti I, the linear drawing compared to local landscape topography, with location of Paleolithic sites 
valley, an important point for hunting strategies. And, as at Pavlov and Kirillevskaia, the small rectangular object placed asymmetrically below corresponds to the location of the Předmostí site, controlling the southwestern edge of the valley. However, this new possible reading of this simple engraving does not mean that the "female" meaning has lost all significance.

The second engraving from Předmostí represents a female without any doubt. A number of explanations, however, have been proposed concerning the strange geometric structuration of the body, the triangular head and the complex linear patterns inside. For some scholars, prehistoric people were simply not yet capable of reproducing shapes realistically; for others, the deformation of shape was drug-stimulated, or may represent a strange kind of a mask. However, several cases recently decoded in Upper Paleolithic art warn us against any simple and unequivocal interpretation. Various "double-meanings" appear repeatedly after more careful examination of some objects, and document a kind of play with forms that was part of prehistoric art production. We agree with Klíma that the two engravings from Předmostí are related and that the simple one may be the key for a better understanding of the complex one. This remains true even if we change the focus and turn the "female" into a "landscape", consisting of a pattern of lines, hatchings, and arrows that recall either a strategic plan of a hunt to take place, or a narrative account of a hunt that has already happened.

\section{Conclusion}

The very fact of intentional mammoth hunting on the Eurasian steppes during the Upper Paleolithic has been the subject of vivid discussion for over a century, and a number of arguments have been raised for and against it. The acceptance of mammoth hunting as an integral part of the Gravettian adaptation system becomes easier if one considers it in context: not only in the context of the huge mammoth bone deposits that were excavated at the Moravian sites as solid proof of some kind of man-and-mammoth relationship, but also in the context of the surrounding landscape and its strategic potential.

The earliest "maps", "plans", or "stories" possibly created by Gravettian hunters fit well into this complex evidence, and comprise some of the first well-documented evidence of actions connected to the daily life of Upper Paleolithic groups.

\section{REFERENCES}

Absolon, K., Klíma, B., 1977, Predmosti ein Mammut-Jägerplatz in Mahren, Fontes Moraviae 8, Praha: Academia.

García-Diez, M., Vaquero, M., 2015, «Looking at the Camp: Paleolithic Depiction of a Hunter-Gatherer Campsite», PlosOne 10 (12): e0143002.

Hahn, J., 1987, "Aurignacian and Gravettian Settlement Patterns in Central Europe», in: The Pleistocene Old World Regional Perspectives, New York and London: Plenum Press, 251-261.

KLÍmA, B., 1955, «Vysledky archelogického vyzkumu na táboristi lovcu mamutu v Petrkovicich, okr. Ostrava v roce 1952 a 1953", Casopis Slezskeho musea v Opavě 4, 1-35.

—, 1963, Dolní Vêstonice. Vyzkum táboristê lovcu mamutu v letech 1947-1952, Praha: Ceskoslovenska Akademie Ved.

—, 1988, «Nejstarší moravská mapa (The earliest Moravian map)», in: Rodná země, Brno, 110-121. 
—, 1995, Dolni Vestonice II. Ein Mammutjägerrastplatz und Seine Bestattungen, ERAUL 73, Liège: Université de Liège.

Kozlowski, J., 1992, L'Art de la Préhistoire en Europa oriental, Éditions du CNRS, Milano: Jaca Books.

Mallery, G., 1886, "Pictographs of the North American Indians», 4th Annual Report of the Bureau of Ethnology, 1882-1883: 7-256.

Marshack, A., 1979, «Upper Paleolithic Symbol Systems of the Russian Plain: Cognitive and Comparative Analysis», Current Anthropology 20.2, 271-311.

Отте, M., 1981, Le Gravettien en Europe centrale, Dissertationes Archaeologicae Gandenses, Brugge: De Tempel.

—, 1992, "Révision de la séquence de Willendorf», in: Les Bassins du Rhin et du Danube au Paleólithique supérieur: environnement, habitat et systèmes d'échange, Actes du XIe Congrès de l'U.I.S.P.P., ERAUL 43, 46-59.

Svoвoda, J., 1984, "Cadre chronologique et tendences évolutives du Paléolithique tchécoslovaque. Essai de synthèse», L'Anthropologie 88.2, 169-192.

—, 2007, «Spatial representations in the Upper Paleolithic: The cases from Pavlov and Předmostí», in: Les expressions intelectuelles et spirituelles des peuples sans écriture, 123-126, Capo di Ponte: UISPP/CISENP.

Svoboda, J. (ed.), 1994, Pavlov I. Excavations 1952-1953, The Dolní Věstonice Studies 2, ERAUL 66, Liège: Université de Liège.

—, 1997, Pavlov I - Nortthwest. The Upper Paléolilithic burial and its settlement context, The Dolní Věstonice Studies 4, Brno: Academy of Sciences of the Czech Republic \& Institute of Archaeology in Brno.

Utrilla, P., Mazo, C., Sopena, M.C., Martínez-Bea, M., Domingo, R., 2009, «A palaeolithic map from 13,660 calBP: engraved stone blocks from the Late Magdalenian in Abauntz Cave (Navarra, Spain)», Journal of Human Evolution 57, 99-111. 